\title{
An Investigation of Tourist Satisfaction on Tourism Destination
}

\author{
Agustinawati ${ }^{1}$ and Muhammad Yusuf ${ }^{2}$ \\ \{. agustinawati@unimal.ac.id $^{1}$, muhd.yusuf@unimal.ac.id ${ }^{2}$ \} \\ ${ }^{1}$ Department of Management, Universitas Malikussaleh Lhokseumawe Aceh, Indonesia \\ ${ }^{2}$ Department of Mechanical Engineering, Universitas Malikussaleh Lhokseumawe Aceh, Indonesia
}

\begin{abstract}
The satisfaction of tourists is an important factor to be considered in the field of service business especially on tourism destinations. This is a standard that can be used to evaluate the performance of tourism services and products. Waduk Jeulikat is the latest tourism destination today in Lhokseumawe Aceh, Indonesia. This location currently very in great demand by the tourists. Waduk Jeulikat was selected as the study area for this research. This study conducted to determine the effect of service quality, attractiveness (natural beauty, uniqueness, diversity) and facilities to the tourist satisfaction and intention to revisit Waduk Jeulikat. This study uses a descriptive approach to determine the variables that affect the tourists satisfaction. The data were collected by using questionnaires distributed directly to tourists visiting the tourism destinations by using accidental sampling. The multiple regression method was used to analyse data. The results showed that all variables simultaneously affect the tourist satisfaction. The most dominant attractiveness factor affects the tourists satisfaction.
\end{abstract}

Keywords: tourism, destination, satisfaction

\section{Introduction}

Today, tourism industry is a major source of income for many countries. Tourism sector in some countries is a priority and mainstay as an effort to mobilize the economy of the community (Nizar, 2015; Set et al., 2015).

Indonesia has the potential in the tourism sector, each region has distinctive features, uniqueness, beauty, and different attractions, and it is able to persuade tourists both local and foreign to visit. The city of Lhokseumawe is one of the districts in the province of Aceh Indonesia. There are many tourism destinations both natural and artificial ones that have been known by domestic and foreign tourists. Some natural tourism destinations have characteristics such as sea, caves, mountains, waterfalls, hot springs, etc. Lhokseumawe also has other artificial tourism destinations such as museums which show historical things, mosques and reservoirs. A number of tourism destination have strong characteristics, therefore, it will indirectly add the income per capita of this district.

Waduk Jeulikat is a reservoir which is one of the artificial tourism destinations in Lhokseumawe. This artificial reservoir has been visited by domestic and foreign tourists. There are various natural beauties that can be enjoyed by tourists who visit these tourism destinations such as the beauty of water reservoirs, mountain sceneries, sunset sceneries, unique stairs, flying fox, rowing boats and culinary.

Customer satisfaction is the main goal for the service industries, it is a benchmark for the success of a business. The service industries must be able to meet the desires, expectations and satisfaction of its customers, thus its customers will return to use their services. Competitive 
strategies for tourism destination today absolutely require the full attention of tourism service managers in managing satisfaction and dissatisfaction. Basically tourism destinations are creating visitors satisfaction, so that they will make repeat visits in the future(Ahmad Puad and Badarneh, 2011) (Gerson, 2002).

Many studies prove that the higher the level of satisfaction will increase the loyalty of tourists visiting the destination (Hermawan, 2017) (Aprilia and Pangestuti, 2017). Customer satisfaction is the customer's perception that their expectations have been met or exceeded (Wiradipoetra and Brahmanto, 2016) (Gerson, 2002). Tourist satisfaction depends on a complex process where the role of each actor is fundamental and it must be in tune with all the other ones (Della Corte, 2015). Attributes related to tourism product of spiritual and cultural nature, atmosphere and climate, a variety of tourist activities, hospitality and safety are significant factors in determining tourist satisfaction, whereas basic facilities such as accommodation, transportation, tourism infrastructure and hygiene and sanitation at destination are of significant importance in satisfaction evaluation (Bagri and Kala, 2015).

This study conducted to determine the effect of service quality, attractiveness (natural beauty, uniqueness, diversity) and facilities to the tourist satisfaction and intention to revisit Waduk Jeulikat.

\section{Literature Review}

\subsection{Tourism and Tourists}

According to Act No 10 of 2009, tourism is tourist activities that are supported by various facilities and services provided by the community, businessmen, and government (Setiawan, 2016). Yoeti, stated that tourism is an activity that is carried out consciously by a person or group of people who travel in a local or overseas area with the aim of getting satisfaction (Tjiptono and Chandra, 2016). Tourists are people who do tourism (Setiawan, 2016)(Tjiptono and Chandra, 2016).

\subsection{Tourism Destinations}

Tourism Destinations are geographical areas that are in one or more administrative areas in which there are tourist attractions, public facilities (such as: security, finance, health, mosques), tourism facilities (such as: accommodation, restaurants, information centers, souvenir shops) accessibility, and society (Setiawan, 2016)(Mufeed and Gulzar, 2014)(Rajesh, 2013).

\subsection{Tourist Satisfaction}

In general, tourist satisfaction can be defined as the level of feeling of a tourist who has visited a tourism destination, then compares the performance of products and services that are perceived or received as expected before. Tjiptono and Gregorius stated that customer satisfaction is an evaluation after purchase with the selected achievement indicators being the same or exceeding customer expectations(Tjiptono and Chandra, 2016). On the other hand, satisfaction is a feeling that is felt after the comparison between product performance and expectations (Della Corte, 2015)(Gerson, 2002). 


\subsection{Service Quality, Attractiveness and Tourism Facilities}

Service quality is a measure of comparison to actual service performance with customer expectations. Service quality is related to the needs and desires of the visitors determined by the company. There are five dimensions used to measure the quality of services, namely: (a) tangible is the physical facilities and infrastructure of the company; (b) Empathy is the attention given by the company to customers; (c) Responsiveness is the company's ability to provide fast service to customers; (d) Reliability is the ability to provide promised services immediately and accurately; (e) Assurance is the ability to create customer trust in the company's services (Kotler and Kevin, 2009)(Sangkaeng, Mananeke and Oroh, 2015)(Alvianna, 2017).

Attractiveness is everything that has uniqueness, beauty, and value in the form of diversity of natural wealth (such as: mountain views, sea, weather), culture (such as: museums, historic sites), and artificial parks that are the target or destination of tourist visits(Hermawan, 2017)(Aprilia and Pangestuti, 2017)(Wiradipoetra and Brahmanto, 2016)(Kirom, . and Adi Putra, 2018).

Tourism facilities are elements in a tourism destination that allows tourists to stay and get services in these destinations, such as: accommodation, restaurants, information center, souvenir shops, and others(Marhanah and Wahadi, 2016).

\section{METHODOLOGY}

Data used in this research were collected from tourism destination of Waduk Jeulikat Lhokseumawe Aceh Indonesia. The data used in this study was collected from the results of a survey conducted by distributing questionnaires in the tourism destinations of the Waduk Jeulikat in Lhokseumawe Aceh Indonesia. This survey was conducted in April 2018, the samples used were local and outside tourists visiting the Waduk Jeulikat tourism destination.

The sample size of this research was determined using the satisfaction interval formula(Sugiyono, 2009). The observed variables service quality, attractiveness, tourism facilities, to comprehend their effects towards the tourist satisfaction. The correlation between variables is drawn in Figure 1.

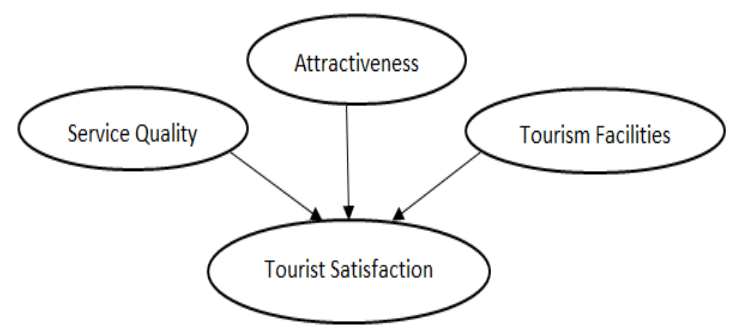

Fig. 1. Research model of correlation between variables towards the tourist satisfaction

Descriptive and inferential analyse were used to analyse the data with the help of a statistics program SPSS for Windows version17.0. Frequency and percentage were used to examine the demographic profile of the respondents. Mean and standard deviation scores were used to present the findings of service quality, attractiveness and tourism facilities towards tourist satisfaction. In addition, regression analysis was used to approximate the variation in tourist satisfaction(Sugiyono, 2009)(Ghozali, 2009). 


\section{Results And Discussion}

\subsection{Reliability}

The reliability analysis of each variable exhibited in Table 1. Since all Cronbach's Alpha values were greater than 0.60, this meant that tested instruments had internal consistency(Ghozali, 2009)

\subsection{Demographic Profiles}

Table 2 presents demographic characteristics of sample. The proportion of men and women is quite different, by $63 \%$ and $33 \%$, respectively. The highest number of respondents in the age group 26-35 years is $38,5 \%$, followed by the age group $36-45$ years as much as $33,3 \%$. Respondents with undergraduate education were the highest number, namely $53,1 \%$ and followed by a diploma with a total of $32,3 \%$. Respondents whose monthly income is IDR $5,000,000-6,000,000$ are the most visited, which is $39,6 \%$.

\subsection{Descriptive Analysis}

Service Quality: Tourist responses about service quality on the tourist satisfaction are tabulated in Table 3. Five attributes are used to measure tourist satisfaction in the quality of services provided. The respondents were satisfied with the quality of service in the Waduk Jeulikat on the attributes include: administration officers, food and beverage providers, guards, and parking services with a range of scores $(4,00-5,00)$. However, the respondents were not satisfied with the attributes of the quality of service at the cottage with a score $(3,73)$.

Table 1. Reliability Score

\begin{tabular}{lll}
\hline Description & $\begin{array}{l}\text { Number } \\
\text { of items }\end{array}$ & $\begin{array}{l}\text { Cronbach's } \\
\text { Alpha }\end{array}$ \\
\hline Service Quality & 5 & 0,63 \\
\hline Attractiveness & 4 & 0,67 \\
\hline Tourism Facilities & 15 & 0,64 \\
\hline Tourist Satisfaction & 5 & 0,72 \\
\hline
\end{tabular}

Table 2. Demographic Characteristics of sample

\begin{tabular}{cccc}
\hline $\begin{array}{c}\text { Demographic } \\
\text { Characteristics }\end{array}$ & $\begin{array}{c}\text { Option } \\
\mathrm{s}\end{array}$ & $\begin{array}{c}\text { Frequenc } \\
\mathrm{y}\end{array}$ & $\begin{array}{c}\text { Perce } \\
\mathrm{n}\end{array}$ \\
\hline Gender & Male & 63 & 65,6 \\
\cline { 2 - 4 } & Female & 33 & 34,4 \\
\hline Age, years & $18-25$ & 14 & 14,6 \\
\cline { 2 - 4 } & $26-35$ & 37 & 38,5 \\
\cline { 2 - 4 } & $36-45$ & 32 & 33,3 \\
\cline { 2 - 4 } $\begin{array}{c}\text { Educational } \\
\text { level }\end{array}$ & $\begin{array}{c}\text { Senior } \\
\text { high } \\
\text { school }\end{array}$ & 7 & 7,3 \\
\cline { 2 - 4 } & $\begin{array}{c}\text { Junior } \\
\text { college }\end{array}$ & 31 & 32,3 \\
\hline
\end{tabular}




\begin{tabular}{cccc}
\hline & $\begin{array}{c}\text { Univer } \\
\text { sity or } \\
\text { college }\end{array}$ & 51 & 53,1 \\
& $\begin{array}{c}\text { Master } \\
\text { or } \\
\text { above }\end{array}$ & 7 & 7,3 \\
& & \\
\hline Monthly & 3.000 .0 & 36 & 37,5 \\
income (IDR) & 00 to & & \\
& 5.000 .0 & & \\
& 00 & & \\
& 5.000 .0 & 38 & 39,6 \\
& 00 to & & \\
& 6.000 .0 & & \\
00 & & 22,9 \\
& $>$ & 22 & \\
& 6.000 .0 & & \\
00 & & \\
\hline
\end{tabular}

Table 3. Descriptive Analysis Of The Service Quality

\begin{tabular}{|c|c|c|c|}
\hline No & Attributes & Mean & $\begin{array}{c}\text { Standard } \\
\text { Deviation }\end{array}$ \\
\hline 1 & $\begin{array}{l}\text { Administrative } \\
\text { officers are very } \\
\text { capable of providing } \\
\text { excellent service }\end{array}$ & 4,32 & 0,47 \\
\hline 2 & $\begin{array}{l}\text { The food and } \\
\text { beverage providers } \\
\text { are very attentive to } \\
\text { the needs of tourists }\end{array}$ & 4,21 & 0,52 \\
\hline 3 & $\begin{array}{l}\text { The guards are very } \\
\text { responsive and } \\
\text { friendly to tourists }\end{array}$ & 4,03 & 0,96 \\
\hline 4 & $\begin{array}{l}\text { Parking services are } \\
\text { very responsive and } \\
\text { responsible }\end{array}$ & 4,01 & 0,94 \\
\hline 5 & $\begin{array}{l}\text { The quality of service } \\
\text { at the cottage is very } \\
\text { clean, cool and } \\
\text { comfortable }\end{array}$ & 3,73 & 0,96 \\
\hline
\end{tabular}

Note: 5- point Likert scale was used to measure the tourist satisfaction Scale: 1 = Very Dissatisfied; 5 = Very Satisfied

Table 4. Descriptive Analysis of the Attractiveness

\begin{tabular}{lcc}
\hline No Attributes & Mean & $\begin{array}{c}\text { Standar } \\
\mathbf{d} \\
\text { Deviatio } \\
\mathbf{n}\end{array}$ \\
\hline
\end{tabular}




\begin{tabular}{llcc}
\hline 1 & $\begin{array}{l}\text { An art show is very } \\
\text { interesting }\end{array}$ & 4,29 & 0,47 \\
\hline 2 & $\begin{array}{l}\text { The scenery of the } \\
\text { sunset }\end{array}$ & 4,27 & 0,46 \\
\hline 3 & $\begin{array}{l}\text { The beauty of } \\
\text { nature }\end{array}$ & 4,00 & 0,73 \\
\hline 4 & $\begin{array}{l}\text { The arrangement of } \\
\text { all the infrastructure }\end{array}$ & 3,80 & 0,70 \\
\hline
\end{tabular}

Note: 5-point Likert scale was used to measure the tourist satisfaction Scale: 1 = Very Dissatisfied; 5 = Very Satisfied

- Attractiveness: Tourist responses about attractiveness on the tourist satisfaction are tabulated in Table 4. Four attributes are used to measure tourist satisfaction in attractiveness provided. The respondents were satisfied with the attractiveness held in the Waduk Jeulikat on the attributes include: art show, the scenery of the sunset and the beauty of nature with a range of scores $(4,00-5,00)$. However, the respondents were not satisfied with the attributes of the arrangement of the infrastructure with a score $(3,80)$.

- Tourism Facilities: Tourist responses about tourism facilities on the tourist satisfaction are tabulated in Table 5. The tourist satisfaction on tourism facilities were measured in 15 attributes. The respondents were satisfied with the tourism facilities held in the Waduk Jeulikat on the attributes include: trash can for each type, many benches, a large parking and facilities are clean with a range of scores $(4,00-5,00)$. However, the respondents were not satisfied with ten of attributes such as canteen, direction to go and et al with a score $(3,80-3,92)$ and their not satisfied with all facilities kept clean $(3,66)$.

Table 5. Descriptive Analysis Of The Tourism Facilities

\begin{tabular}{llcc}
\hline No & \multicolumn{1}{c}{ Attributes } & Mean & $\begin{array}{c}\text { Standar } \\
\text { d } \\
\text { Deviatio } \\
\text { n }\end{array}$ \\
\hline 1 & $\begin{array}{l}\text { A sufficient } \\
\text { trash for each } \\
\text { type }\end{array}$ & 4,33 & 0,47 \\
\hline 2 & $\begin{array}{l}\text { many benches } \\
\text { in the park }\end{array}$ & 4,16 & 0,67 \\
\hline 3 & $\begin{array}{l}\text { A large parking } \\
\text { safe }\end{array}$ & 4,07 & 0,89 \\
\hline 4 & $\begin{array}{l}\text { All existing } \\
\text { facilities are } \\
\text { clean, }\end{array}$ & 4,02 & 0,72 \\
\hline 5 & $\begin{array}{l}\text { canteens clean } \\
\text { and comfortable }\end{array}$ & 3,92 & 1,03 \\
\hline 6 & $\begin{array}{l}\text { The facilities } \\
\text { well maintained }\end{array}$ & 3,90 & 0,72 \\
\hline 7 & $\begin{array}{l}\text { There is a clear } \\
\text { direction to go }\end{array}$ & 3,88 & 0,81 \\
\hline 8 & All game areas & 3,87 & 1,05 \\
\hline
\end{tabular}




\begin{tabular}{|c|c|c|c|}
\hline No & Attributes & Mean & $\begin{array}{c}\text { Standar } \\
\text { d } \\
\text { Deviatio } \\
\text { n }\end{array}$ \\
\hline & $\begin{array}{l}\text { are very safe to } \\
\text { use }\end{array}$ & & \\
\hline 9 & $\begin{array}{l}\text { Toilets clean } \\
\text { and comfortable }\end{array}$ & 3,86 & 0,84 \\
\hline 10 & $\begin{array}{l}\text { flower garden } \\
\text { and shelter }\end{array}$ & 3,85 & 0,71 \\
\hline 11 & $\begin{array}{l}\text { The state of the } \\
\text { facility that is } \\
\text { good and } \\
\text { comfortable to } \\
\text { use makes } \\
\text { tourists } \\
\text { interested }\end{array}$ & 3,84 & 0,85 \\
\hline 12 & $\begin{array}{l}\text { facilities for } \\
\text { children and } \\
\text { adults }\end{array}$ & 3,82 & 1,15 \\
\hline 13 & $\begin{array}{l}\text { Facilities for } \\
\text { prayer }\end{array}$ & 3,80 & 0,84 \\
\hline 14 & $\begin{array}{l}\text { Water tourism } \\
\text { comfortable. }\end{array}$ & 3,80 & 0,76 \\
\hline 15 & $\begin{array}{l}\text { All facilities } \\
\text { kept clean }\end{array}$ & 3,66 & 1,00 \\
\hline
\end{tabular}

Note: 5- point Likert scale was used to measure the tourist satisfaction Scale: 1 = Very Dissatisfied; 5 = Very Satisfied

Regression Analyses

The relationship between all attributes and overall tourist satisfaction is shown in Table 6. Based on the results of regression analysis, it can be interpreted that all variables are significant $(0,000)$. All the attributes contributed to tourist satisfaction.

Satisfaction in tourism destination is based on the differences between expectation and experiences after tourists visited the destination. If the comparison between experiences and expectations results in a feeling of pleasure, the tourist is satisfied or dissatisfaction if it results in feelings of displeasure(Reisinger, Y. \& Turner, no date)(Aziz et al., 2011). Table 6 shows a significant regression model had existed $\left[F(7,209)>F_{\text {table }}(3,095)\right.$ or Sig. $p(0,000)<\alpha$ $(0,05)]$. The regression model implied that tourist satisfaction will significantly contribute to tourism destination. Satisfaction explained approximately $19,0 \%\left(R^{2}=0,190\right)$ of total variance in tourist satisfaction. There was a positive and have correlation $(R=0,436)$ between tourist satisfaction on tourism destination. Therefore that, tourism destination contibute to tourist satisfaction. Tourist satisfaction should be monitored continuously to obtain up-to-date and precise information from tourists. This will help to predict revisit intention and recommended to others. 
Table 6. The Regression Model On Tourist Satisfaction

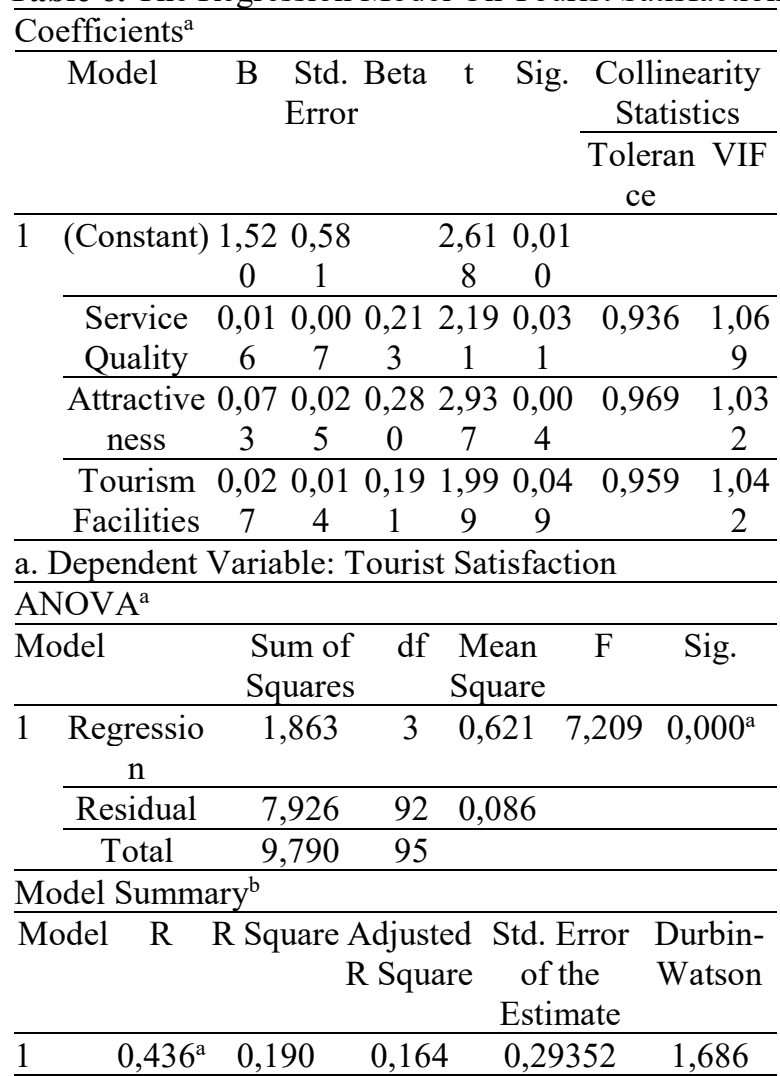

a. Predictors: (Constant), service quality, attractiveness, tourism facilites

b. Dependent Variable: tourist satisfaction

\section{Conclusions}

Based on the research result and the discussion about the tourist satisfaction on tourism destination, it can be concluded that; The overall, the attractiveness of tourism destinations in Waduk Jeulikat is quite interesting. Althought, there are several conditition that need to be fixed, especially the conditions that associated with tourism facilities kept clean, facilities for prayer, facilities for children/adults and canteen. The service quality provide on tourism destination in Waduk Jeulikat is still needs to be improved to create tourist satisfaction, revisit intention and recomended to others.

\section{Acknowledgment}

The author acknowledge thank you so much especially for Ms. Mutia as student in faculty of economic and business Universitas Malikussaleh for all support in this research. 


\section{References}

[1] Ahmad Puad, M. S. and Badarneh, M. B. (2011) 'Tourist satisfaction and repeat visitation; toward a new comprehensive model', International Journal of Human and Social Sciences, 6(1), pp. 38-45. doi: 10.1016/S1007-0214(09)70057-4.

[2] Alvianna, S. (2017) 'Analisis Pengaruh Harga, Produk, Dan Kualitas Layanan Terhadap Kepuasan Wisatawan Di Taman Wisata Air Wendit Kabupaten Malang', Pesona, 2(01), pp. 1-12.

[3] Aprilia, E. R. and Pangestuti, E. (2017) 'Pengaruh daya tarik wisata dan fasilitas layanan terhadap kepuasan wisatawan di pantai balekambang kabupaten malang', Jurnal Administrasi Bisnis (JAB), 51(2), pp. 16-21.

[4] Aziz, N. A., Ariffin, A. A. M., Omar, N. A. and Yoon, S. K. (2011) 'An Investigation of International and Domestic Tourists' Satisfactionin Heritage Context: Implications for Destination Marketing', Jurnal Pengurusan, 33, pp. 61-76.

[5] Bagri, S. and Kala, D. (2015) 'Tourists' satisfaction at Trijuginarayan: An emerging spiritual and adventure tourist destination in Garhwal Himalaya India', Turizam, 19(4), pp. 165-182. doi: 10.5937/Turizam1504165B.

[6] Della Corte, V. (2015) 'Customer Satisfaction in Tourist Destination: The Case of Tourism Offer in the City of Naples', Journal of Investment and Management, 4(1), p. 39. doi: 10.11648/j.jim.s.2015040101.16.

[7] Gerson, R. F. (2002) 'Mengukur Kepuasan Pelanggan'. Jakarta: PPM.

[8] Ghozali, I. (2009) 'Aplikasi Analisis Multivariate dengan Program SPSS'.

[9] Hermawan, H. (2017) Pengaruh Daya Tarik Wisata, Keselamatan, Dan Sarana Wisata Terhadap Kepuasan Serta Dampaknya Terhadap Loyalitas Wisatawan.

[10] Kirom, N. R., . S. and Adi Putra, I. W. J. (2018) 'The Influence of Tourist Attractions Towards the Tourists' Satisfaction', KnE Social Sciences, 3(3), p. 270. doi: $10.18502 / \mathrm{kss} . v 3 \mathrm{i} 3.1889$.

[11] Kotler, P. and Kevin, K. (2009) 'Manajemen Pemasaran. Edisi Kedua Belas, PT Indeks, Jakarta'. Jakarta: Erlangga.

[12] Marhanah, S. and Wahadi, W. H. (2016) 'PENGUNJUNG DI TAMAN MARGASATWA THE INFLUENCE OF TOURISM FACILITIES AND QUALITY OF SERVICE TO CUSTOMER SATISFACTION AT TAMAN MARGASATWA', 13(1).

[13] Mufeed, S. A. and Gulzar, R. (2014) 'Tourism in Saudi Arabia', (3), pp. 167-178.

[14] Nizar, M. A. (2015) Effect Of Tourism On International Trade In Indonesia, MPRA Paper No. 65631.

[15] Rajesh, R. (2013) 'Impact of Tourist Perceptions, Destination Image and Tourist Satisfaction on Destination Loyalty: A Conceptual Model', Www.Pasosonline.Org, 11, pp. 67-78. doi: 10.25145/j.pasos.2013.11.039.

[17] Reisinger, Y.\& Turner, L. W. (no date) 'Cross-cultural behaviour in tourism: Concepts and analysis'.

[18] Sangkaeng, S., Mananeke, L. and Oroh, S. G. (2015) 'The Influence of Citra Tourism, Tourism Promotion and Quality of Service For Tourists Satisfaction Attractions Uses Attractions Bunaken Marine Park at North Sulawesi', Jurnal EMBA, 3(3), pp. 10891100 .

[19] Set, K., Yaakop, A. Y., Zatul, N., Hussin, I. and Mohd, B. (2015) 'Understanding Motivation Factors of Tourism Entrepreneurs in Tasik Kenyir', 1(2), pp. 248-254.

[20] Setiawan, W. (2016) 'Undang-Undang Republik Indonesia', pp. 1-40. 
[21] Sugiyono (2009) 'Metode Penelitian Administrasi dilengkapi Metode R\&D'. Bandung: Alfabeta.

[22] Tjiptono, F. and Chandra, G. (2016) 'Service Quality dan Satisfaction'. Yogyakarta: Andi.

[23] Wiradipoetra, F. A. and Brahmanto, E. (2016) 'Analisis persepsi wisatawan mengenai penurunan kualitas daya tarik wisata terhadap minat berkunjung', Jurnal Pariwisata, $3(2)$,

pp.

129-137. 